\title{
Altered Prelimbic Cortex Output during Cue-Elicited Drug Seeking
}

\author{
Courtney A. Miller and John F. Marshall \\ Department of Neurobiology and Behavior, University of California, Irvine, Irvine, California 92697
}

Cocaine treatment paired with environmental cues establishes a conditioned place preference (CPP) for that environment. After expression of this preference, rats show elevated levels of immediate early genes (IEGs; e.g. c-fos) in the prelimbic cortex (PrL), basolateral amygdala complex (BLC), and nucleus accumbens core (NAcc) compared with drug-unpaired controls. These findings, together with the known connections between these regions, suggest that they function as a circuit contributing to cue-elicited craving. To investigate the function of this circuit during drug-seeking, we characterized Fos immunoreactivity of particular neuron classes in each region. To distinguish between IEG activation of GABAergic and non-GABAergic (principally, excitatory projection) neurons, we combined Fos immunohistochemistry with immunohistochemistry for glutamic acid decarboxylase $67\left(\mathrm{GAD}_{67}\right)$ or calcium/calmodulin-dependent protein kinase II (CAMKII) proteins. Within the BLC and NAcc of drug-paired and drug-unpaired animals tested for CPP, we observed no significant differences in the percentage of Fos-immunoreactive (IR) cells that were also $\mathrm{GAD}_{67}$-IR. We also observed no group difference in the degree of Fos/CAMKII overlap in the BLC. However, in PrL, the degree of Fos/GAD $/ \mathrm{D}_{67}$ overlap in the drug-paired group was significantly higher than in the drug-unpaired group. Also, the Fos/CAMKII overlap in the entire PrL as well as just its layer V was significantly lower in the drug-paired animals compared with controls. These findings suggest that, during CPP expression in cocainepaired animals, the PrL GABAergic interneurons are preferentially activated while PrL output is attenuated, perhaps through greater inhibition of layer $\mathrm{V}$ pyramidal neurons. These results suggest a shifting prefrontal cortex cell population response during cocaineseeking.

Key words: cocaine; conditioned place preference; immediate early gene; prelimbic cortex; nucleus accumbens; basolateral amygdala; c-Fos

\section{Introduction}

Repeated pairing of cues with psychostimulant drugs of abuse can lead to rapid, intense learning of an association between the cues and the rewarding effects of the drugs. This learning can contribute importantly to human drug relapse. When abstinent drug abusers encounter the cues, they experience a conditioned physiological response and intense craving (Jaffe, 1990). Cueelicited craving is modeled in rats using several paradigms, including conditioned place preference (CPP). Rats receiving cocaine in one distinctive chamber of a place preference apparatus learn to associate the rewarding effects of cocaine with that the environmental context of that chamber. Once this association is formed, animals placed in the CPP apparatus spend more time in the cocaine-paired chamber.

Previous studies showed that the circuitry underlying cueelicited drug seeking prominently involves several forebrain

Received May 3, 2004; revised June 22, 2004; accepted June 22, 2004.

This research was supported by National Institute on Drug Abuse (NIDA) Grant 1R01 DA 13649-01A2 to J.F.M. C.A.M. was supported by NIDA Training Grant DA 07318. We thank Dr. Danielle Simmons for advice regarding immunolabeling, Dr. Jennifer Trevitt for advice regarding statistical analyses, and Dr. Janet Neisewander for comments on the experimental design and this manuscript.

Correspondence should be addressed to Dr. John F. Marshall, Department of Neurobiology and Behavior, University of California, 2205 McGaugh Hall, Irvine, CA 92627-4550. E-mail: jfmarsha@uci.edu.

D0I:10.1523/JNEUROSCI.1685-04.2004

Copyright $\odot 2004$ Society for Neuroscience $\quad$ 0270-6474/04/246889-09\$15.00/0 structures, including the basolateral amygdala complex (BLC; lateral and basolateral amygdala), prelimbic cortex (PrL), and nucleus accumbens core (NAcc). The involvement of these structures in cue-elicited drug seeking conforms to other evidence indicating that (1) the basolateral amygdala (BLA) contributes to the modulation of emotional memories (Cahill and McGaugh, 1998; Pare, 2003), (2) as part of the prefrontal cortex the PrL contributes to executive decision-making processes of response initiation and inhibition (Iversen and Mishkin, 1970; Weissenborn et al., 1997; Bechara et al., 2000; Taylor et al., 2003), and (3) the NAcc lies at the interface of motivation and movement (Mogenson et al., 1980). Human brain imaging studies support a high correlation between blood flow or metabolic activity of these regions and self-reports of craving by addicts who are presented with stimuli commonly associated with cocaine use (e.g., pictures of drug paraphernalia) (Grant et al., 1996; Childress et al., 1999; Wang et al., 1999). Animal research, using pharmacological manipulations, lesions, and electrophysiological recordings, further supports the contributions of each of these brain regions to cueelicited craving (Isaac et al., 1989; Hiroi and White, 1991; Tzschentke and Schmidt, 1999; Carelli and Ijames, 2001).

Although much evidence implicates these three brain regions in cue-elicited craving and drug seeking, little is known about the identity of activated cells within these regions or the processes coordinating their activities. This research investigates how these 
brain regions interact and influence one another to drive stimulus-induced drug seeking.

We trained animals in a CPP apparatus to associate one chamber with cocaine. Animals were later tested for their place preference in a drug-free state and killed to assess neuron activation within regions of the PrL-BLC-NAcc circuit using immediate early gene (Fos) immunohistochemistry (IHC). Because inhibitory interactions, particularly between the PrL and BLA (Perez-Jaranay and Vives, 1991; Rosenkranz and Grace, 2001, 2002), appear important for cue-elicited craving, we examined overlap between Fos and $\mathrm{GAD}_{67}$, the GABA synthesis enzyme, to determine to what extent the activated cells in the PrL, BLC, and NAcc are GABAergic. We then examined overlap between Fos and a marker for non-GABAergic (principally, excitatory projection) neurons, calcium/ calmodulin-dependent protein kinase II (CAMKII) (Ouimet et al., 1984; Pinaudeau-Nasarre et al., 2002). The aim of these double-labeling studies was to determine, for each region, the extent to which neuronal activation occurred in these distinct neuron populations.

\section{Materials and Methods}

Animals. Male Sprague Dawley rats, weighing 250-275 gm, were housed individually on a $12 \mathrm{hr}$ light/dark cycle with ad libidum access to food and water. The housing conditions and care of the animals were consistent with those specified in the Guide for the Care and Use of Laboratory Animals (Institute of Laboratory Animal Resources on Life Science, National Research Council, 1996). Animals were handled for $5 \mathrm{~d}$ before behavioral conditioning.

Place-preference apparatus. Conditioning took place in a threechamber apparatus consisting of two larger compartments $(29.2 \times 25.4$ $\mathrm{cm})$ separated by a smaller compartment $(11.4 \times 25.4 \mathrm{~cm})$. The two larger compartments had different visual, tactile, and olfactory cues. One compartment had white walls and a wire mesh floor above pine shavings. The other compartment had black and white checkered walls and a bargrid floor above cedar shavings. The middle compartment had a checkered wall and a white wall that led into the corresponding larger compartments. Also, this compartment had the same corn cob bedding as the home cage and a bar grid floor. The apparatus had a clear Plexiglas top to allow observation during testing. On conditioning days, removable partitions were put in place, separating the three compartments.

Control environment. In addition to being placed in the compartments of the conditioning chamber, animals were placed in an alternate environment for control purposes as described below. The control environment consisted of a clear plastic cage $(27 \times 48 \mathrm{~cm})$, distinct from the home cage, located in a room independent of both the CPP apparatus and holding rooms.

Behavioral conditioning. Baseline preferences were assessed by placing the animals $(n=20)$ in the center compartment and allowing free access to the entire apparatus for $15 \mathrm{~min}$. Time spent in each side was calculated for each animal and then averaged across the entire group. Because there was no significant overall preference for either compartment initially, we arbitrarily chose to pair the cocaine injections with the checkered compartment. Conditioning then took place over the next $9 \mathrm{~d}$ (Fig. 1). The animals were divided into a drug-paired $(n=10)$ and a drug-unpaired $(n=10)$ group, such that each group had an equal mean initial time spent in each compartment. The drug-unpaired group served as a control for drug treatment itself. These animals received volumes of cocaine- $\mathrm{HCl}$ $(10 \mathrm{mg} / \mathrm{kg}$, i.p.; Sigma, St. Louis, MO) equal to those administered to the drug-paired animals, but given in the control environment. On days 1, 4, and 7 , the drug-paired animals received saline injections $(1 \mathrm{ml} / \mathrm{kg}$, i.p.) before placement in the control environment. A counterbalanced design was used for the CPP conditioning days such that on days 2, 5, and 8 half of the drug-paired animals received injections of cocaine immediately before placement in the checkered compartment. The other half of the drug-paired animals received saline before placement in the white compartment. On days 3, 6, and 9, the treatment and side were alternated. The drug-unpaired animals received saline injections before placement in both CPP compartments on days $1,2,4,5,7$, and 8. Training was counterbalanced so that half of the animals were first placed in the white compartment and half were placed in the checkered compartment. On days 3,6 , and 9 , the drug-unpaired animals received cocaine injections before placement in the control environment. Animals remained in the respective environments for $30 \mathrm{~min}$ each day. Forty-eight hours after the last conditioning session, preference was assessed as described previously for testing baseline preferences.

Retrograde labeling of $\operatorname{PrL}$ neurons projecting to NAcc. An additional group of six rats, not exposed to CPP testing, was prepared to identify PrL neurons that project to the NAcc. Six Sprague Dawley rats, weighing 275-300 gm, were anesthetized with equithesin $(4.2 \mathrm{ml} / \mathrm{kg}$, i.p. $)$ and secured in a Kopf stereotaxic apparatus. Micropipettes filled with $2 \%$ Fluoro-Gold (FG; Fluorochrome, Englewood, CO) in 0.9\% saline were aimed at the NAcc [anteroposterior: $1.6 \mathrm{~mm}$ relative to bregma; mediolateral: $2.3 \mathrm{~mm}(n=3),-2.3 \mathrm{~mm}(n=3)$; dorsoventral: $-7.6 \mathrm{~mm}$, from skull (Paxinos and Watson, 1998)]. Tracer was applied iontophoretically for 10 min using an alternating ( $10 \mathrm{sec}$ on, 10 sec off) direct current of +5 $\mu \mathrm{A}$. Afterward, the pipette remained in place for another $5 \mathrm{~min}$ before it was removed from the brain and the scalp wound was sutured closed.

Tissue preparation for immunohistochemistry. Rats were killed for Fos immunohistochemistry $90 \mathrm{~min}$ after the end of the final preference test. In most neurons, basal levels of c-fos mRNA and Fos protein are low and levels increase with cellular excitation, which makes both useful markers for neuronal activation (Greenberg and Ziff, 1984). The induction of c-fos is rapid and transient after a stimulus, with the translation of Fos protein reaching its peak after 60-120 min (Curran et al., 1984, 1985; Muller et al., 1984). Although Fos is widely used as a marker for cellular activation, the relationship between Fos expression and patterns of neuronal firing is complex (Labiner et al., 1993). Animals used for retrograde labeling were killed $7 \mathrm{~d}$ after FG iontophoresis. All animals were anesthetized deeply with sodium pentobarbitol $(50 \mathrm{mg} / \mathrm{kg}$, i.p.) and perfused transcardially with ice-cold $0.1 \mathrm{~m} \mathrm{PBS}, \mathrm{pH} 7.4$, followed by ice-cold $4 \%$ paraformaldehyde in $0.1 \mathrm{~m}$ PBS, $\mathrm{pH}$ 7.4. The brains were removed, postfixed overnight at $4^{\circ} \mathrm{C}$, and then transferred to $30 \%$ sucrose for $48 \mathrm{hr}$ at $4^{\circ} \mathrm{C}$. Coronal sections $(40 \mu \mathrm{m})$ were collected at levels corresponding to $3.2 \mathrm{~mm}$ [PrL, infralimbic cortex (IL)], $1.6 \mathrm{~mm}$ [NAcc, caudate-putamen 
$(\mathrm{CPu})]$, and $-2.8 \mathrm{~mm}$ [BLC, central amygdala (CeA)] from bregma (Paxinos and Watson, 1998) using a freezing microtome.

Fos-glutamic acid decarboxylase $67\left(G A D_{67}\right)$ double immunohistochemistry. Sections from all three levels collected were first labeled for Fos and then $\mathrm{GAD}_{67}$ immunoreactivity. Sections were rinsed in $0.3 \% \mathrm{H}_{2} \mathrm{O}_{2}$ and then $0.1 \mathrm{M}$ PBS, followed by incubation in $0.1 \mathrm{M}$ PBS containing $5 \%$ normal goat serum (NGS) (Vector Laboratories, Burlingame, CA) for 1 $\mathrm{hr}$. Sections were then incubated for $48 \mathrm{hr}$ at $4^{\circ} \mathrm{C}$ in $0.1 \mathrm{M} \mathrm{PBS}$ containing anti-Fos rabbit polyclonal antibody (PC-38; 1:15,000; Oncogene Science, Cambridge, MA) and 1\% NGS. The sections were then rinsed in $0.1 \mathrm{M}$ PBS and incubated in $0.1 \mathrm{M}$ PBS containing biotinylated goat anti-rabbit IgG (1:200; Vector Laboratories) and 1\% NGS for $1 \mathrm{hr}$. The sections were then rinsed again in $0.1 \mathrm{M}$ PBS and incubated with avidin-biotinylated peroxidase complex (ABC) (ABC Elite kit; Vector Laboratories) for $1 \mathrm{hr}$. The reaction was terminated by rinsing the tissue in $0.1 \mathrm{M}$ PBS. The tissue was then incubated in a 1:1 dilution of nickel-enhanced diaminobenzidine tetrahydrochloride (purple/black reaction product; Vector Laboratories) for $5 \mathrm{~min}$. This reaction was terminated by rinsing the tissue in 0.1 M Tris buffer, $\mathrm{pH}$ 7.4. The $\mathrm{GAD}_{67}$ immunolabeling was begun immediately afterward, with extensive tissue rinses before the $\mathrm{GAD}_{67}$ primary antibody was added. Tissue was first rinsed in $0.3 \% \mathrm{H}_{2} \mathrm{O}_{2}$. Sections were then rinsed in $0.1 \mathrm{M}$ PBS and incubated in $0.1 \mathrm{M}$ PBS containing 5\% NGS and avidin D (biotin blocking kit; Vector Laboratories) for $1 \mathrm{hr}$. Sections were then incubated for $24 \mathrm{hr}$ in $0.1 \mathrm{M}$ PBS containing 1\% NGS, anti$\mathrm{GAD}_{67}$ rabbit polyclonal antibody (AB5992; 1:2000; Chemicon, Temecula, CA), and biotin solution (biotin blocking kit; Vector Laboratories). The sections were then rinsed in $0.1 \mathrm{M}$ PBS and incubated in $0.1 \mathrm{M}$ PBS containing biotinylated goat anti-rabbit IgG and 1\% NGS for $1 \mathrm{hr}$. The sections were then rinsed again in $0.1 \mathrm{M}$ PBS and incubated with $\mathrm{ABC}$ for $1 \mathrm{hr}$. The reaction was terminated by rinsing the tissue in $0.1 \mathrm{M}$ PBS. The tissue was then incubated in a 1:2 dilution of nonmetal-enhanced $\mathrm{DAB}$ (light amber reaction product; Vector Laboratories) for $5 \mathrm{~min}$. This reaction was terminated by rinsing the tissue in $0.1 \mathrm{M}$ Tris buffer. Sections were then mounted onto gelatin-coated slides, dried, and dehydrated ( $95 \%$ and then $100 \% \mathrm{EtOH}$ for $5 \mathrm{~min}$ each) before coverslipping.

Because both primary antibodies (Fos and $\mathrm{GAD}_{67}$ ) were raised in rabbit, we tested the specificity of the Fos- $\mathrm{GAD}_{67}$ colocalization. Sections were processed for both Fos (Ni-enhanced $\mathrm{DAB}$ ) and $\mathrm{GAD}_{67}$ (nonenhanced $\mathrm{DAB}$ ) IHC, but the primary antibody to $\mathrm{GAD}_{67}$ was omitted. We found equal numbers of Ni-enhanced DAB-labeled cells in motor cortex, caudate-putamen, and NAcc in both conditions (data not shown), indicating that addition of anti-rabbit secondary antibody in a second immunoreaction produced no anomalous additional labeling that would incorrectly be interpreted as Fos.

Fos-CAMKII double immunohistochemistry. Sections corresponding to the PrL and BLC of the same animals were also processed for Fos and CAMKII immunoreactivity. Because $\sim 95 \%$ of striatal neurons, including those of the nucleus accumbens, represent GABAergic neurons (Groves, 1983), no attempt was made to label CAMKII-immunoreactive (-IR) neurons in the NAcc. Fos immunohistochemistry was performed as described previously. After the completion of the Fos immunoreaction, sections were rinsed in $0.3 \% \mathrm{H}_{2} \mathrm{O}_{2}$. Sections were then rinsed in 0.1 м PBS and incubated in $0.1 \mathrm{M}$ PBS containing $5 \%$ normal horse serum (NHS; Vector Laboratories), $0.2 \%$ Triton X-100 (Sigma), and avidin D for $1 \mathrm{hr}$. Tissue was then incubated for $48 \mathrm{hr}$ in $0.1 \mathrm{~m} \mathrm{PBS}$ containing $1 \%$ NHS, $0.1 \%$ Triton X-100, biotin solution, and anti-CAMKII $\alpha$ subunit mouse monoclonal antibody (MA1-048; 1:200; Affinity Bioreagents, Golden, CO). The sections were then rinsed in $0.1 \mathrm{~m}$ PBS and incubated in $0.1 \mathrm{M}$ PBS containing biotinylated horse anti-mouse IgG (1:200; Vector Laboratories) and 1\% NHS for $1 \mathrm{hr}$. The sections were then rinsed again in $0.1 \mathrm{M}$ PBS and incubated with $\mathrm{ABC}$ for $1 \mathrm{hr}$. The reaction was terminated by rinsing the tissue in $0.1 \mathrm{M}$ PBS. The tissue was then incubated in nonmetal-enhanced $\mathrm{DAB}$ for $5 \mathrm{~min}$. This reaction was terminated by rinsing the tissue in $0.1 \mathrm{M}$ Tris buffer. Tissue was then mounted and coverslipped as described previously.

FG immunohistochemistry. FG immunolabeling was performed as described for Fos with the following exceptions. The nonspecific and primary solutions contained $0.2 \%$ Triton X-100, the primary antibody was an anti-FG rabbit polyclonal antibody (AB153; Chemicon) used at
1:5000, and the labeling was visualized with a 1:3 dilution of the Vector SG substrate kit (blue reaction product).

Immunoreactivity quantification. Distributions of immunoreactive cells were studied by viewing the tissue with an Olympus Opticals (Tokyo, Japan) microscope at $40 \times$ magnification. All cells immunoreactive for Fos were counted by hand in the PrL (an approximate area of $4 \mathrm{~mm}^{2}$ at $3.2 \mathrm{~mm}$ relative to bregma), IL (an approximate area of $2 \mathrm{~mm}^{2}$ at 3.2 $\mathrm{mm}$ relative to bregma), NAcc (approximate area of $2 \mathrm{~mm}^{2}$ at $1.6 \mathrm{~mm}$ relative to bregma), $\mathrm{CPu}$ (approximate area of $3 \mathrm{~mm}^{2}$ at $1.6 \mathrm{~mm}$ relative to bregma), BLC (approximate area of $1.75 \mathrm{~mm}^{2}$ at $-2.8 \mathrm{~mm}$ relative to bregma), and CeA (approximate area of $1 \mathrm{~mm}^{2}$ at $-2.8 \mathrm{~mm}$ relative to bregma). In addition, all cells immunoreactive for $\mathrm{GAD}_{67}$ or CAMKII, as well as cells double labeled for Fos and either $\mathrm{GAD}_{67}$ or CAMKII, were counted by hand in the PrL, NAcc, and BLC. A count of the number of Fos-CAMKII double-labeled cells was also confined to layer V of the PrL. Fos-ir cells were identified by a purple-black reaction product confined to the nucleus, whereas $\mathrm{GAD}_{67}$ and CAMKII-ir cells were identified by an amber reaction product in the cytoplasm. Double-labeled cells were identified by a purple-black nucleus surrounded by amber cytoplasm. Cells were quantified in both hemispheres of two sections. The counts were then averaged to give a mean number of each immunoreactive cell type per area. These counts were then divided by the area of the corresponding region to give cells counts per square millimeter. The percentage of cells expressing Fos that were $\mathrm{GAD}_{67}$-IR or CAMKII-IR was computed by dividing the number of double-labeled cells by the number of Fos-IR cells per region for each animal.

Statistical analysis. The experimenter was blind to treatment groups when taking all measures. Wilcoxon signed-ranks tests were conducted to compare the amount of time spent in the checkered versus the white compartments during the initial and final tests. A simple main effects analysis was conducted to determine any shift in time spent in the cocaine-paired chamber between baseline and the final test day. One-way ANOVAs for each region were conducted to determine differences in the numbers of Fos, $\mathrm{GAD}_{67}$, and CAMKII-IR cells, as well as the number of double-labeled cells, in the tissue of drug-paired and unpaired animals.

\section{Results}

\section{Conditioning to a cocaine-paired environment}

In the initial preference testing, animals showed no significant preference for either the white or checkered compartments of the CPP apparatus $(z=-0.22 ; p>0.05)$. After behavioral conditioning, drug-paired, but not drug-unpaired, animals showed a significant preference for the cocaine-paired compartment on the final test day $(z=-2.80, p<0.01$ and $z=-1.38, p>0.05$, respectively) (Fig. 2). Also, drug-paired animals showed a significant increase in the amount of time spent in the cocaine-paired compartment compared with pretreatment baseline (mean \pm SEM time at baseline $=321.4 \pm 22.3 \mathrm{sec}$ ) to the final test day (final test $=428.9 \pm 33.4 \mathrm{sec} ; F_{(9)}=9.83, p<0.025$ ); however, drug-unpaired animals did not show a shift in preference $\left(F_{(9)}=\right.$ $3.58 ; p>0.05)$. These findings demonstrate the development of a preference for the environment previously paired with cocaine.

\section{Fos activation induced by expression of CPP}

Fos immunoreactivity was examined in animals after the conditioned place preference testing. Quantification was performed in two sets of tissue from the same animals, in which Fos immunoreactivity was combined with either $\mathrm{GAD}_{67}$ or CAMKII immunoreactivity. For each set of tissue, significantly greater numbers of Fos-IR neurons were observed in the $\operatorname{PrL}\left(F_{(19)}=18.95, p<\right.$ $\left.0.001 ; F_{(19)}=10.96, p<0.01\right), \operatorname{NAcc}\left(F_{(19)}=17.12, p<0.005\right)$, and $\operatorname{BLC}\left(F_{(19)}=9.29, p<0.01 ; F_{(19)}=20.44, p<0.001\right)$ of drug-paired animals, as compared with drug-unpaired control animals (Fig. 3). In contrast, there were no differences in the number of Fos-IR neurons in the IL $\left(F_{(19)}=1.08 ; p>0.05\right), \mathrm{CPu}$ $\left(F_{(19)}=0.99 ; p>0.05\right)$, or $\operatorname{CeA}\left(F_{(19)}=0.01 ; p>0.05\right)$. These 
data confirm that the expression of a conditioned preference for a cocaine-paired environment induces greater immediate early gene (IEG) activation within the PrL, BLC, and NAcc and that this Fos activation displays anatomic specificity (Brown et al., 1992; Crawford et al., 1995; Neisewander et al., 2000; Ciccocioppo et al., 2001).

\section{Degree of overlap between Fos and $\mathrm{GAD}_{67}$ after CPP expression}

$\mathrm{GAD}_{67}$ was used as a marker of GABAergic neurons. No significant differences were observed in the numbers of $\mathrm{GAD}_{67}$-IR cells between drug-paired and unpaired animals in any of the brain regions of interest (PrL: $F_{(19)}=0.06, p>0.05$; NAcc: $F_{(19)}=0.06$, $p>0.05$; BLC: $\left.F_{(19)}=0.002, p>0.05\right)$, suggesting consistent $\mathrm{GAD}_{67}$ immunolabeling between the groups. Also, drug-paired and drug-unpaired animals did not differ in the percentage of Fos-IR cells that were also $\operatorname{GAD}_{67}$-IR in the NAcc $\left(F_{(19)}=1.80\right.$; $p>0.05)$ (Fig. 4$)$ or the $\operatorname{BLC}\left(F_{(19)}=1.34 ; p>0.05\right)$ (Fig. 4$)$; however, a significantly greater proportion of Fos-IR cells were Fos- $\mathrm{GAD}_{67}$ double labeled in the PrL of the drug-paired group compared with the drug-unpaired group $\left(F_{(19)}=41.11 ; p<\right.$ 0.001 ) (Fig. 4). Figure 5 shows the correspondence of Fos-IR nuclei and $\mathrm{GAD}_{67}$-IR neuronal cytoplasm in the PrL of drugpaired and unpaired animals. These results suggest a greater inhibition within the PrL of drug-paired animals on exposure to a cocaine-paired environment.

\section{Degree of overlap between Fos and CAMKII after CPP expression}

CAMKII was used as a marker of non-GABAergic (principally, excitatory projection) neurons in the BLC and PrL. Because $\sim 95 \%$ of striatal neurons, including those of the NAcc, represent GABAergic neurons (Groves, 1983), no attempt was made to label CAMKII-IR neurons in the NAcc. No significant differences were observed between drug-paired and drug-unpaired animals in the numbers of CAMKII-IR cells in either brain region (PrL: $F_{(19)}=1.59, p>0.05$; BLC: $\left.F_{(19)}=1.31, p>0.05\right)$, indicating consistent CAMKII immunolabeling across groups. Also, drugpaired and drug-unpaired groups showed no significant differences in the percentage of Fos-IR cells that were also CAMKII-IR in the BLC $\left(F_{(19)}=0.09 ; p>0.05\right)$ (Fig. $\left.6 B\right)$; however, the number of Fos-CAMKII double-labeled cells in the $\operatorname{PrL}\left(F_{(19)}=4.94\right.$; $p<0.05$ ) (Fig. 6A) as well as the proportion of Fos-IR cells in the PrL that were Fos-CAMKII double labeled $\left(F_{(19)}=31.97 ; p<\right.$ 0.001 ) (Figs. $6 B, 7$ ) were significantly lower in the drug-paired than in the drug-unpaired group. These results suggest an attenuated IEG activation of the PrL excitatory neurons in drug-paired animals during expression of a preference for the cocaine-paired environment.

\section{Degree of overlap between Fos and CAMKII after CPP expression in PrL layer $\mathrm{V}$}

Using retrograde FG labeling, we observed that layers II/III and V of PrL contain large numbers of neurons projecting to the NAcc, and we confirmed the findings from previous studies demonstrating that layer $\mathrm{V}$ of this cortical region contains the largest number of retrogradely labeled cells (McGeorge and Faull, 1989; Groenewegen et al., 1990) (Fig. 8). Consequently, the FosCAMKII quantification was repeated with analysis confined to layer V of the PrL. As for the entire PrL, the number of FosCAMKII double-labeled neurons in layer $\mathrm{V}\left(F_{(19)}=11.45 ; p<\right.$ 0.005) (Fig. 6A) as well as the percentage of Fos-IR cells in this

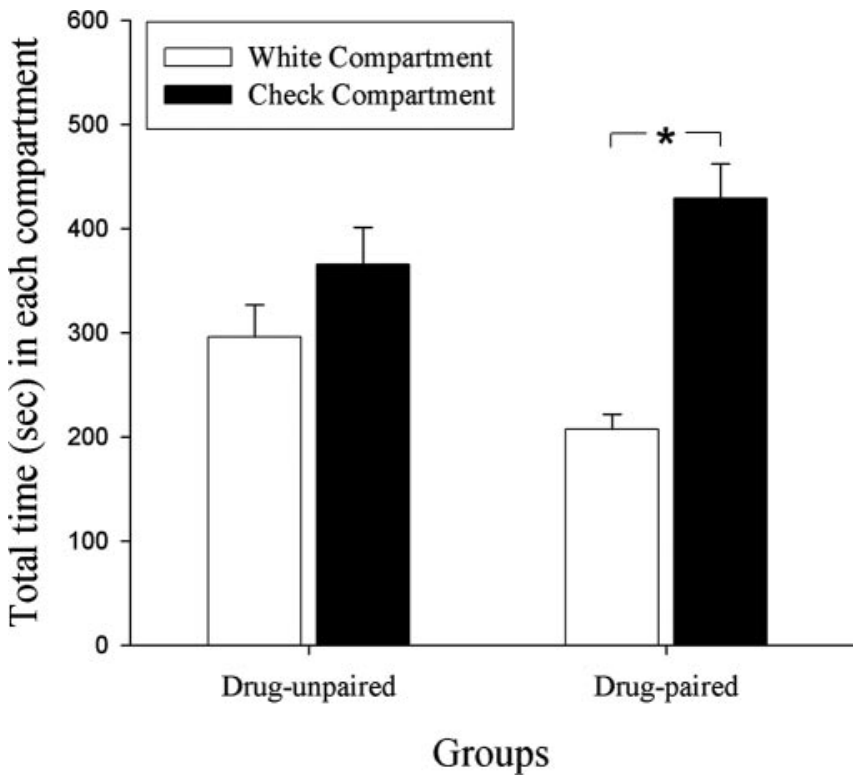

Figure 2. Expression of (PP. Time spent in checkered compartment (cocaine paired) versus white compartment (saline paired) in drug-unpaired and drug-paired animals on final test day. ${ }^{*} p<0.01$; Wilcoxon signed-ranks test. Baseline means for checkered compartment (308.6 $18.3 \mathrm{sec}$ ) and white compartment (313.6 $\pm 16.2 \mathrm{sec})$ did not differ significantly $(p>0.05)$.

layer that were Fos-CAMKII double labeled $\left(F_{(19)}=33.81 ; p<\right.$ $0.001)$ were less in drug-paired animals than unpaired animals (Fig. 6b). These findings provide additional evidence of decreased activation of PrL output neurons in drug-paired animals as compared with controls, during expression of cocaine CPP.

\section{Discussion}

\section{Differential activation of PrL GAD 67 -IR and CAMKII-IR neurons}

The principal finding of this study is that rats expressing a preference for an environment previously associated with cocaine administration demonstrate differential activation of the immediate early gene, c-fos, within two subpopulations of prelimbic cortex neurons. Animals of the drug-paired and drug-unpaired groups showed no difference in Fos expression in the $\mathrm{CeA}, \mathrm{CPu}$, or IL. The drug-paired animals expressing CPP showed greater IEG activation in the BLC, NAcc, and PrL compared with drugunpaired animals, but subpopulations of BLC or NAcc neurons were similarly activated in their IEG expression. Within the PrL, in contrast, greater overall Fos activation in drug-paired animals was accompanied by a shift in the neuron population expressing this IEG, such that more PrL Fos-IR cells were Fos-GAD 67 and fewer were Fos-CAMKII double labeled. Strikingly, the drugpaired group, despite overall higher levels of PrL Fos-IR nuclei, had fewer PrL Fos-CAMKII double-labeled neurons compared with unpaired controls. Although c-fos induction bears a complex relationship with neuron firing rates and patterns (Labiner et al., 1993), the most parsimonious explanation for these prelimbic cortex findings is that rats expressing CPP had greater activity in the GABAergic inhibitory neurons of the PrL but diminished PrL output. Therefore, despite the overall greater numbers of Fos-IR nuclei, PrL outputs may be underactive during cue-elicited drug-seeking behavior.

Immunohistochemistry for CAMKII $\alpha$ subunit provides a useful marker for non-GABAergic, noncholinergic, nonmonoaminergic excitatory neurons of the brain. The cerebral cortical 


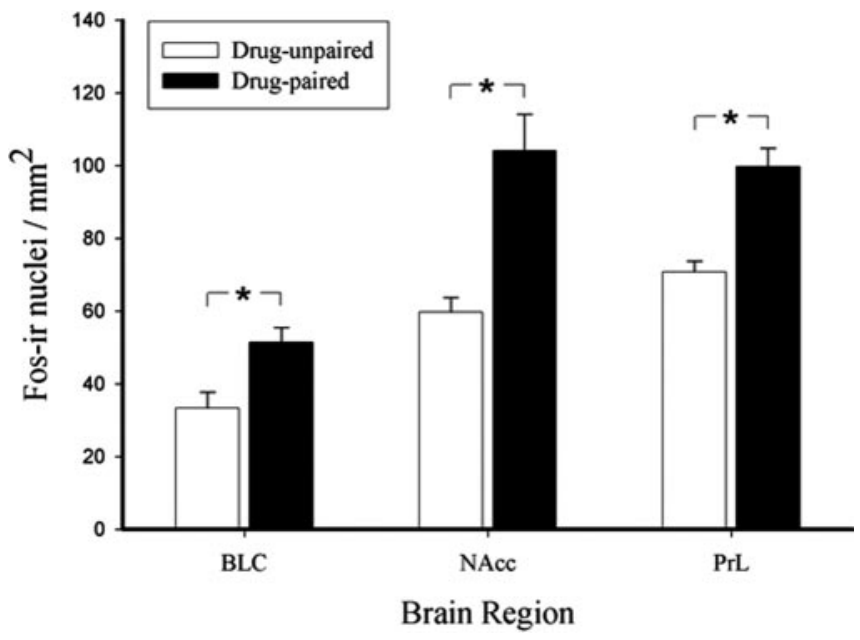

Figure 3. Quantification of Fos expression per square millimeter in BLC, NAcc, and PrL of drug-paired versus unpaired animals. ${ }^{*} p<0.01$; one-way ANOVAs.

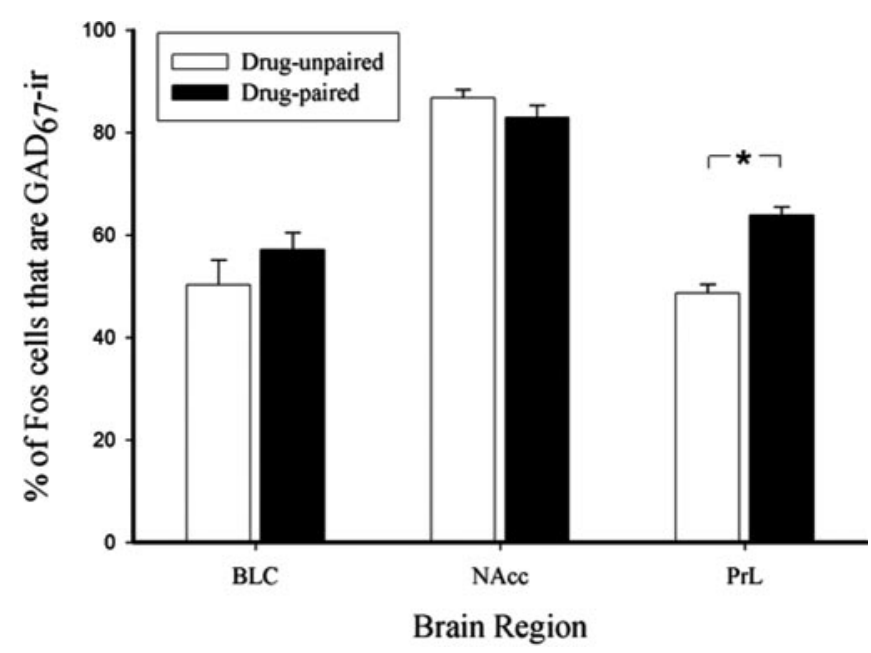

Figure 4. Fos- $\mathrm{GAD}_{67}$ overlap in the BLC, NAcc, and PrL after CPP testing of drug-paired versus unpaired animals. Data are expressed as the percentage of Fos-IR cells in each region that are $G_{A D}-I R$. Greater Fos $-G_{A D}$ double-labeled neurons were found in PrL, but not BLC or NAcc, of drug-paired animals. ${ }^{*} p<0.001$; one-way ANOVA.

CAMKII-IR neurons include both pyramidal neurons and smaller, nonpyramidal neurons (Ouimet et al., 1984; Fukunaga et al., 1988; Ochiishi et al., 1994). Neurons expressing $\mathrm{GAD}_{67}$ and CAMKII exist as essentially separate populations. Studies combining in situ hybridization and immunohistochemistry have reported no overlap between $\mathrm{GAD}_{67}$ and CAMKII neurons in the monkey forebrain and diencephalon (Benson et al., 1991; Jones et al., 1994).

Most of the output of the PrL to the NAcc comes from the large pyramidal neurons of layer V (McGeorge and Faull, 1989; Groenewegen et al., 1990), a conclusion that we confirmed by visualizing FG in these neurons after iontophoresis into the NAcc. Because CAMKII heavily labels pyramidal neurons of this layer (Ouimet et al., 1984; Pinaudeau-Nasarre et al., 2002), we repeated the quantification of Fos and CAMKII overlap within layer V only. As was observed for the entire PrL, both the numbers and proportions of Fos-IR cells that were Fos-CAMKII double labeled were significantly less in drug-paired animals compared with unpaired animals.
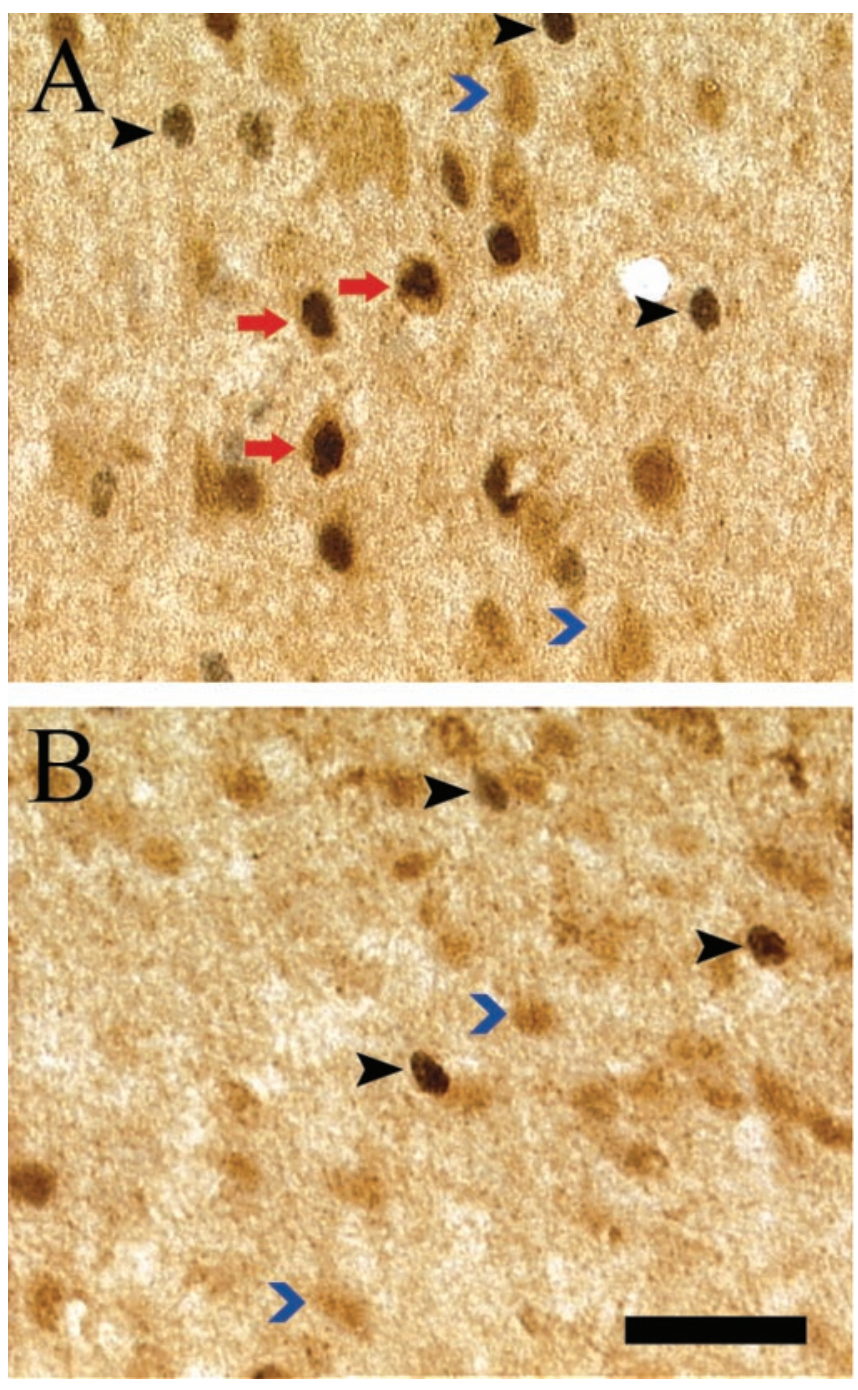

Figure 5. Fos and $\mathrm{GAD}_{67}$ colocalization after (PP testing. High-power photomicrographs $(40 \times)$ of individually immunolabeled $\mathrm{GAD}_{67}$ (blue arrowhead) and Fos-IR (black arrowhead) neurons and double-labeled ( $\mathrm{GAD}_{67}-\mathrm{IR}$ and Fos-IR) neurons (red arrow) in representative drugpaired $(A)$ and drug-unpaired $(B)$ animals. Scale bar, $20 \mu \mathrm{m}$.

BLC, NAcc, and PrL involvement in cue-elicited drug seeking Our finding that exposure to a cocaine-paired environment increased immediate early gene expression in the BLC, NAcc, and PrL fits a large body of evidence pointing to the involvement of these structures in drug seeking and craving. Other studies examining Fos and Fos-related antigens after exposure to a cocainepaired environment reported increased levels in the BLC, NAcc, and PrL (Brown et al., 1992; Franklin and Druhan, 2000; Neisewander et al., 2000; Ciccocioppo et al., 2001). Human imaging studies confirm the involvement of these regions, showing metabolic activation or enhanced blood flow in the medial prefrontal cortex (mPFC) and amygdala of abstinent cocaine addicts after presentation of cocaine-paired cues (Grant et al., 1996; Maas et al., 1998; Childress et al., 1999; Wang et al., 1999).

Animal research has shown that an intact BLC is necessary for acquiring a conditioned association between the rewarding effects of a drug and environmental cues, but not for experiencing the reward (Whitelaw et al., 1996). Preconditioning and postconditioning BLC lesions disrupt cue-elicited cocaine-seeking behavior (Hiroi and White, 1991; Brown and Fibiger, 1993; Fuchs et al., 2002). Whether the PrL is required for cue-elicited drug seek- 

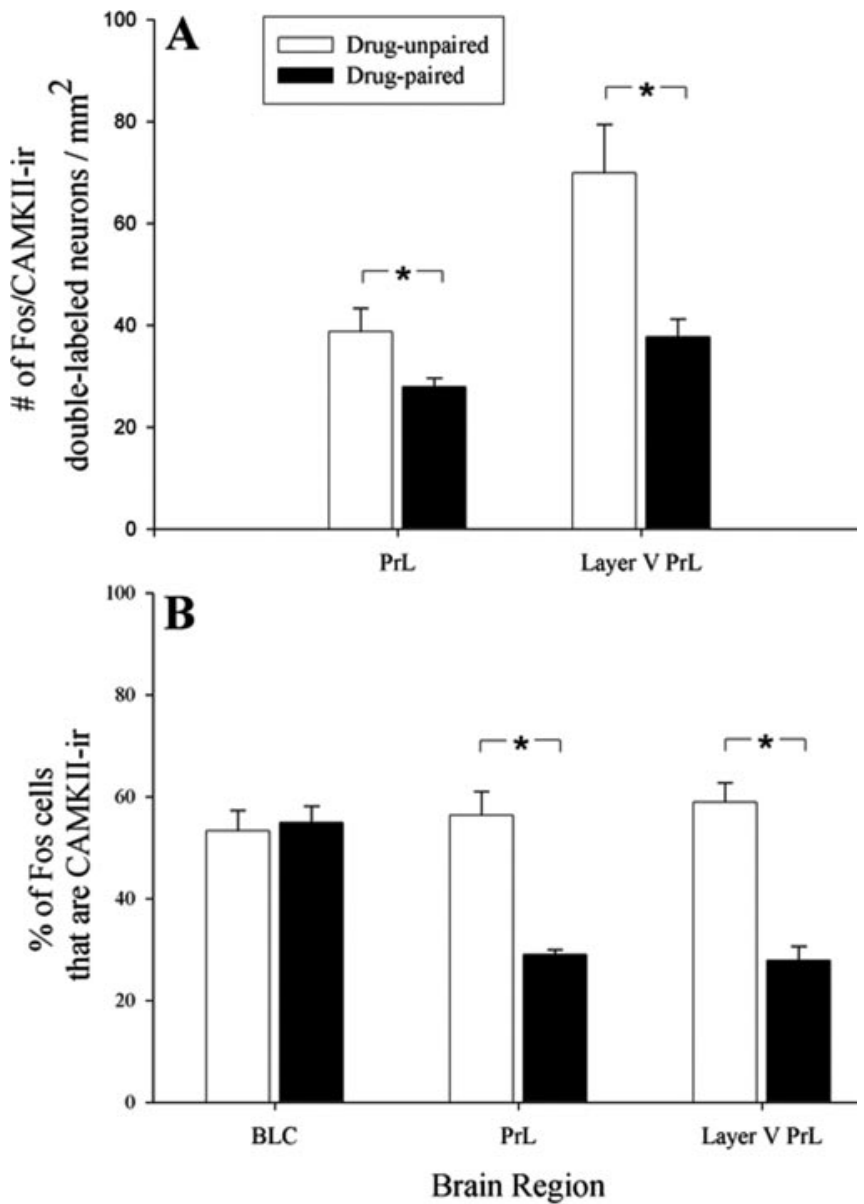

Figure 6. Fos-CAMKII overlap in the BLC, PrL, and Layer V PrL after CPP testing of drugpaired versus unpaired groups $(A)$. Data in $B$ are expressed as the percentage of Fos-IR cells in each region that are Fos-CAMKIII-IR. Fewer Fos-CAMKII double-labeled neurons were found in entire PrL and PrL layer V of drug-paired animals compared with unpaired controls. ${ }^{*} p<0.001$; one-way ANOVAs.

ing is more controversial, because preconditioning excitotoxic lesions of the PrL blocked the acquisition of cocaine CPP in one study (Tzschentke and Schmidt, 1999) but failed to do so in another (Zavala et al., 2003). Also, presenting a stimulus paired previously with cocaine or amphetamine administration increases firing in NAc cells (Carelli and Ijames, 2001) and enhances NAc dopamine release (Di Ciano et al., 1998; Weiss et al., 2000).

\section{Neural circuitry involved in cue-elicited craving}

Although our experiments do not address mechanisms by which the establishment of a cocaine CPP shifts the IEG response of the GABAergic and projection populations within the PrL, previous investigations suggest some possibilities. The BLA and PrL have direct reciprocal projections (Groenewegen et al., 1990; McDonald, 1991; McDonald et al., 1996). It seems likely that the BLC projection neurons innervating the PrL show enhanced activity during CPP expression (as suggested by greater Fos levels in BLC of drug-paired animals) and that an enhanced activity of BLC outputs results predominantly in inhibition of PrL neurons. BLC electrical stimulation inhibits $63.5 \%$ and excites $8.5 \%$ of the mPFC neurons recorded. All responses studied showed either pure inhibition or excitation followed by inhibition (Perez-Jaranay and Vives, 1991). Similarly, tone-conditioned fear, which potentiates the responses of BLA neu-
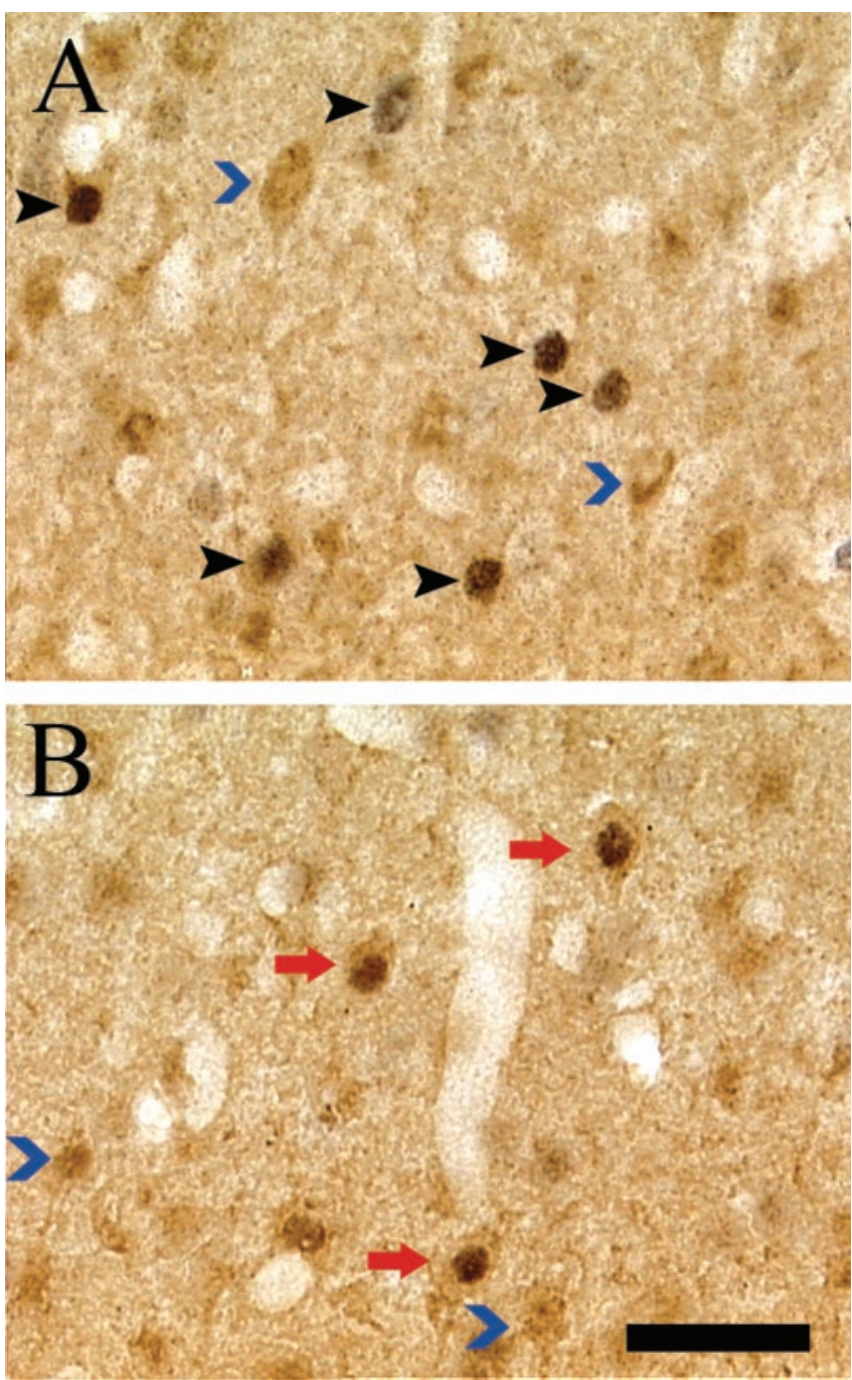

Figure 7. Fos and CAMKII colocalization after (PP testing. High-power photomicrographs $(40 \times)$ of individually immunolabeled CAMKII (blue arrowhead) and Fos-IR (black arrowhead) neurons and double-labeled (CAMKIIIIR and Fos-IR) neurons (red arrow) in representative drug-paired $(A)$ and drug-unpaired $(B)$ animals. Scale bar, $20 \mu \mathrm{m}$.

rons to tones signaling shock occurrence, suppresses the spontaneous firing of PrL neurons (Garcia et al., 1999), an effect dependent on the amygdala (Garcia et al., 1999); however, an ultrastructural analysis of BLC terminations within $\mathrm{mPFC}$ revealed that all synaptic specializations examined were asymmetric, commonly associated with excitatory synapses, and 97\% of these were axospinous (Bacon et al., 1996). The authors suggest that these BLC-derived inputs target the dendritic spines of both pyramidal neurons and spiny local circuit GABAergic neurons and that the excitation of local circuit neurons provides feedforward inhibition of other cortical neurons (Bacon et al., 1996).

\section{Implications of altered PrL output}

The decreased IEG expression in PrL output neurons of animals expressing cocaine CPP accords with the finding of Thomas and Everitt (2001) of decreased PrL expression of $\gamma$ protein kinase $C$ during retrieval of a cocaine-associated light stimulus; however, these results appear to contrast with conclusions from several recent studies suggesting that activation of the $\mathrm{mPFC}$ is necessary for cocaine-, stress-, and cue-primed reinstatement of cocaine 

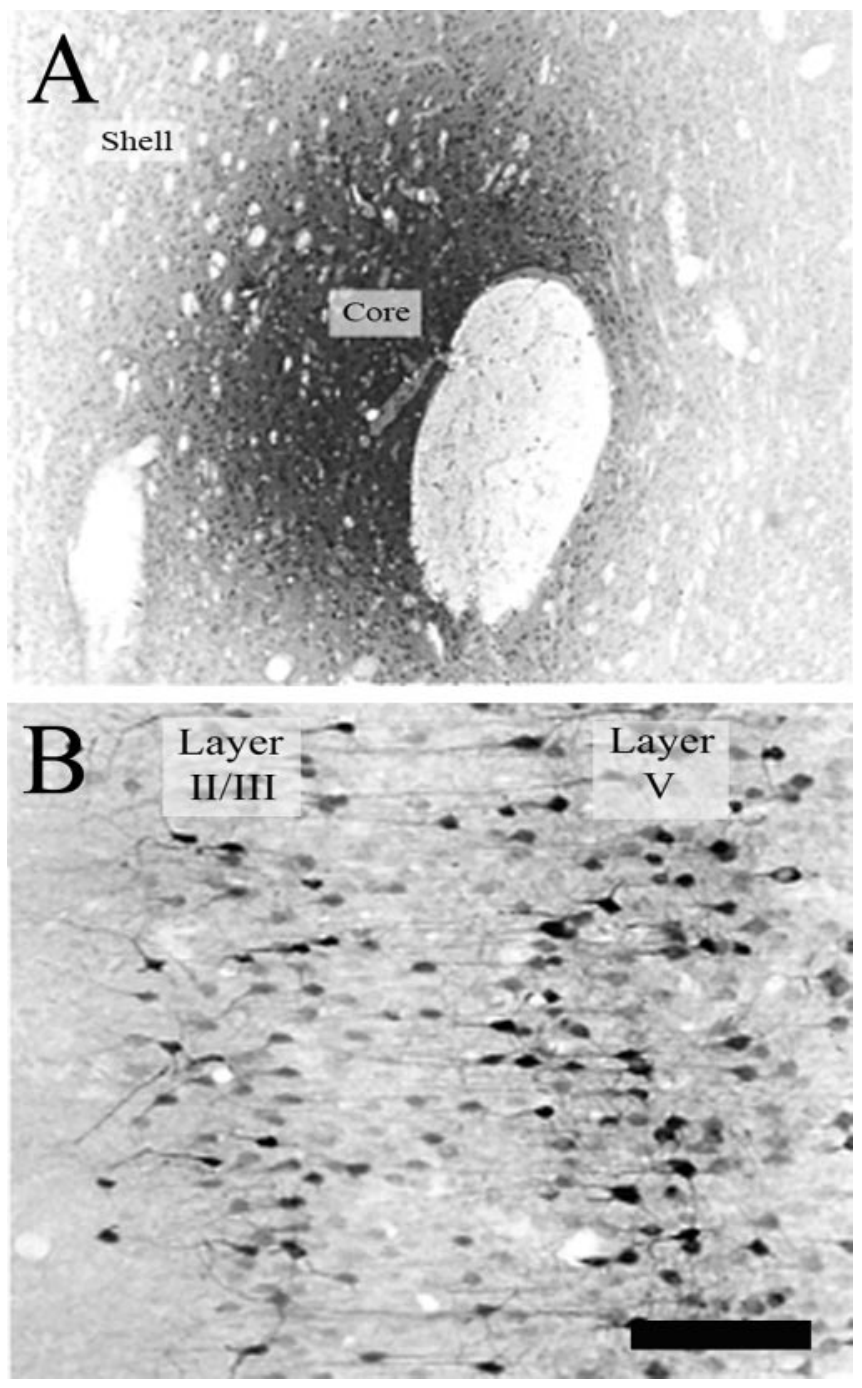

Figure 8. Photomicrographs depicting representative Fluorogold iontophoresis site in the $\operatorname{NAcc}(A)$ and resulting $F G$ retrograde labeling in PrL layer V and layers II/III ( $B$ ). Scale bars: $A, 280$ $\mu \mathrm{m} ; B, 120 \mu \mathrm{m}$

seeking. Using a self-administration paradigm followed by extinction, the reinstatement of lever pressing normally induced by either cocaine priming or footshock was abolished when testing was immediately preceded by inactivation of either the dorsal PFC (anterior cingulate and dorsal PrL) or PrL (Capriles et al., 2003; McFarland et al., 2003, 2004). Furthermore, McLaughlin and See (2003) reported that mPFC infusions of tetrodotoxin antagonized cue-elicited reinstatement of lever pressing. Although it is not surprising that the involvement of PrL in drug seeking during CPP may differ from its involvement in cocaineor stress-elicited reinstatement, the contrast between the present findings and those of McLaughlin and See (2003) is more puzzling. Distinctions between the behavioral paradigms used in our studies may contribute to the differing conclusions. The selfadministration method used a discrete compound stimulus (light plus tone) presented only when the active lever was pressed, whereas the CPP procedure uses predictive contextual stimuli that distinguish the two CPP chambers but are present during the entire training and testing periods. See (2002) has shown that associative learning dependent on discrete versus contextual stimuli can involve different brain regions. A second possibility is that the decreased numbers of PrL Fos-CAMKII neurons reflect a focusing of output to neurons specifically involved in drug seeking. Additional experiments will be needed to determine which PrL output cells are influenced in Fos expression during CPP expression. Third, the observed modulations of Fos induction in $\operatorname{PrL} \mathrm{GAD}_{67}$ and CAMKII cell populations could occur as a result of CPP expression, perhaps as part of a delayed feedback process.

The present findings, however, support more directly another growing body of research pointing to diminished PFC functioning in drug abusers. A structural analysis performed on the brains of cocaine abusers revealed decreased gray matter in the orbitofrontal cortex (OFC) compared with nonabusers (Franklin et al., 2002). Cocaine abusers often exhibit behavioral abnormalities similar to those observed in patients with orbitofrontal damage, including denial of their problem and choosing immediate rewards, despite knowing the future negative consequences of the decision (Bechara et al., 2001). During performance of a gambling task, both OFC lesion patients and psychostimulant (cocaine or methamphetamine) abusers performed poorly, consistently choosing cards from the high-risk, low-payoff deck (Bechara et al., 2001).

Many studies have examined the role of OFC in response inhibition. In primates, both acute and chronic cocaine administration impaired reversal of a previously learned object discrimination task but had no effect on acquisition of a novel one. The reversal learning impairments after chronic cocaine were perseverative in nature, with animals consistently choosing the previously rewarded object (Jentsch et al., 2002). Thus, intermittent, repeated cocaine administration is sufficient to produce dysfunction in the prefrontal cortex. Also, rats with lesions of PrL and IL demonstrate perseveration and disinhibition under a secondorder reinforcement schedule in which a drug-paired stimulus serves as a conditioned reinforcer, and they maintain lever pressing in the absence of drug delivery (Weissenborn et al., 1997), confirming its role in response inhibition.

In conclusion, our findings accord with a growing body of evidence from both human and animal studies that suggests decreased prefrontal cortex functioning in drug abusers. Additional experiments, using retrograde labeling of PrL neurons after tracer injections into the NAcc and BLC, are needed to establish whether the activation of the projection from the PrL to either of these regions is specifically diminished during cue-elicited cocaine-seeking behavior.

\section{References}

Bacon SJ, Headlam AJ, Gabbott PL, Smith AD (1996) Amygdala input to medial prefrontal cortex (mPFC) in the rat: a light and electron microscope study. Brain Res 720:211-219.

Bechara A, Damasio H, Damasio AR (2000) Emotion, decision making and the orbitofrontal cortex. Cereb Cortex 10:295-307.

Bechara A, Dolan S, Denburg N, Hindes A, Anderson SW, Nathan PE (2001) Decision-making deficits, linked to a dysfunctional ventromedial prefrontal cortex, revealed in alcohol and stimulant abusers. Neuropsychologia 39:376-389.

Benson DL, Isackson PJ, Hendry SH, Jones EG (1991) Differential gene expression for glutamic acid decarboxylase and type II calcium-calmodulindependent protein kinase in basal ganglia, thalamus, and hypothalamus of the monkey. J Neurosci 11:1540-1564.

Brown EE, Fibiger HC (1993) Differential effects of excitotoxic lesions of the amygdala on cocaine-induced conditioned locomotion and conditioned place preference. Psychopharmacology (Berl) 113:123-130.

Brown EE, Robertson GS, Fibiger HC (1992) Evidence for conditional neuronal activation following exposure to a cocaine-paired environment: role of forebrain limbic structures. J Neurosci 12:4112-4121. 
Cahill L, McGaugh JL (1998) Mechanisms of emotional arousal and lasting declarative memory. Trends Neurosci 21:294-299.

Capriles N, Rodaros D, Sorge RE, Stewart J (2003) A role for the prefrontal cortex in stress- and cocaine-induced reinstatement of cocaine seeking in rats. Psychopharmacology (Berl) 168:66-74.

Carelli RM, Ijames SG (2001) Selective activation of accumbens neurons by cocaine-associated stimuli during a water/cocaine multiple schedule. Brain Res 907:156-161.

Childress AR, Mozley PD, McElgin W, Fitzgerald J, Reivich M, O’Brien CP (1999) Limbic activation during cue-induced cocaine craving. Am J Psychiatry 156:11-18.

Ciccocioppo R, Sanna PP, Weiss F (2001) Cocaine-predictive stimulus induces drug-seeking behavior and neural activation in limbic brain regions after multiple months of abstinence: reversal by $\mathrm{D}(1)$ antagonists. Proc Natl Acad Sci USA 98:1976-1981.

Crawford CA, McDougall SA, Bolanos CA, Hall S, Berger SP (1995) The effects of the kappa agonist U-50,488 on cocaine-induced conditioned and unconditioned behaviors and Fos immunoreactivity. Psychopharmacology (Berl) 120:392-399.

Curran T, Miller AD, Zokas L, Verma IM (1984) Viral and cellular fos proteins: a comparative analysis. Cell 36:259-268.

Curran T, Bravo R, Muller R (1985) Transient induction of c-fos and c-myc in an immediate consequence of growth factor stimulation. Cancer Surv 4:655-681.

Di Ciano P, Blaha CD, Phillips AG (1998) Conditioned changes in dopamine oxidation currents in the nucleus accumbens of rats by stimuli paired with self-administration or yoked-administration of D-amphetamine. Eur J Neurosci 10:1121-1127.

Franklin TR, Druhan JP (2000) Expression of Fos-related antigens in the nucleus accumbens and associated regions following exposure to a cocaine-paired environment. Eur J Neurosci 12:2097-2106.

Franklin TR, Acton PD, Maldjian JA, Gray JD, Croft JR, Dackis CA, O’Brien CP, Childress AR (2002) Decreased gray matter concentration in the insular, orbitofrontal, cingulate, and temporal cortices of cocaine patients. Biol Psychiatry 51:134-142.

Fuchs RA, Weber SM, Rice HJ, Neisewander JL (2002) Effects of excitotoxic lesions of the basolateral amygdala on cocaine-seeking behavior and cocaine conditioned place preference in rats. Brain Res 929:15-25.

Fukunaga K, Goto S, Miyamoto E (1988) Immunohistochemical localization of $\mathrm{Ca}^{2+} /$ calmodulin-dependent protein kinase II in rat brain and various tissues. J Neurochem 51:1070-1078.

Garcia R, Vouimba RM, Baudry M, Thompson RF (1999) The amygdala modulates prefrontal cortex activity relative to conditioned fear. Nature 402:294-296.

Grant S, London ED, Newlin DB, Villemagne VL, Liu X, Contoreggi C, Phillips RL, Kimes AS, Margolin A (1996) Activation of memory circuits during cue-elicited cocaine craving. Proc Natl Acad Sci USA 93:12040-12045.

Greenberg ME, Ziff EB (1984) Stimulation of 3T3 cells induces transcription of the c-fos proto-oncogene. Nature 311:433-438.

Groenewegen HJ, Berendse HW, Wolters JG, Lohman AH (1990) The anatomical relationship of the prefrontal cortex with the striatopallidal system, the thalamus and the amygdala: evidence for a parallel organization. Prog Brain Res 85:95-118.

Groves PM (1983) A theory of the functional organization of the neostriatum and the neostriatal control of voluntary movement. Brain Res 286:109-132.

Hiroi N, White NM (1991) The lateral nucleus of the amygdala mediates expression of the amphetamine-produced conditioned place preference. J Neurosci 11:2107-2116.

Isaac WL, Nonneman AJ, Neisewander J, Landers T, Bardo MT (1989) Prefrontal cortex lesions differentially disrupt cocaine-reinforced conditioned place preference but not conditioned taste aversion. Behav Neurosci 103:345-355.

Iversen SD, Mishkin M (1970) Perseverative interference in monkeys following selective lesions of the inferior prefrontal convexity. Exp Brain Res 11:376-386.

Jaffe JH (1990) Drug addiction and drug abuse. In: The pharmacological basis of therapeutics (Gilman AG, Rall TW, Nies AS, Taylor P, eds), pp 522-573. New York: Pergamon.

Jentsch JD, Olausson P, De La Garza II R, Taylor JR (2002) Impairments of reversal learning and response perseveration after repeated, intermittent cocaine administrations to monkeys. Neuropsychopharmacology 26:183-190.

Jones EG, Huntley GW, Benson DL (1994) $\alpha$ Calcium/calmodulindependent protein kinase II selectively expressed in a subpopulation of excitatory neurons in monkey sensory-motor cortex: comparison with GAD-67 expression. J Neurosci 14:611-629.

Labiner DM, Butler LS, Cao Z, Hosford DA, Shin C, McNamara JO (1993) Induction of c-fos mRNA by kindled seizures: complex relationship with neuronal burst firing. J Neurosci 13:744-751.

Maas LC, Lukas SE, Kaufman MJ, Weiss RD, Daniels SL, Rogers VW, Kukes TJ, Renshaw PF (1998) Functional magnetic resonance imaging of human brain activation during cue-induced cocaine craving. Am J Psychiatry 155:124-126.

McDonald AJ (1991) Organization of amygdaloid projections to the prefrontal cortex and associated striatum in the rat. Neuroscience 44:1-14.

McDonald AJ, Mascagni F, Guo L (1996) Projections of the medial and lateral prefrontal cortices to the amygdala: a Phaseolus vulgaris leucoagglutinin study in the rat. Neuroscience 71:55-75.

McFarland K, Lapish CC, Kalivas PW (2003) Prefrontal glutamate into the core of the nucleus accumbens mediates cocaine-induced reinstatement of drug-seeking behavior. J Neurosci 23:3531-3537.

McFarland K, Davidge SB, Lapish CC, Kalivas PW (2004) Limbic and motor circuitry underlying footshock-induced reinstatement of cocaine-seeking behavior. J Neurosci 24:1551-1560.

McGeorge AJ, Faull RL (1989) The organization of the projection from the cerebral cortex to the striatum in the rat. Neuroscience 29:503-537.

McLaughlin J, See RE (2003) Selective inactivation of the dorsomedial prefrontal cortex and the basolateral amygdala attenuates conditioned-cued reinstatement of extinguished cocaine-seeking behavior in rats. Psychopharmacology 168:57-65.

Mogenson GJ, Jones DL, Yim CY (1980) From motivation to action: functional interface between the limbic system and the motor system. Prog Neurobiol 14:69-97.

Muller R, Bravo R, Burckhardt J, Curran T (1984) Induction of c-fos gene and protein by growth factors precedes activation of c-myc. Nature 312:716-720.

Neisewander JL, Baker DA, Fuchs RA, Tran-Nguyen LT, Palmer A, Marshall JF (2000) Fos protein expression and cocaine-seeking behavior in rats after exposure to a cocaine self-administration environment. J Neurosci 20:798-805.

Ochiishi T, Terashima T, Yamauchi T (1994) Specific distribution of $\mathrm{Ca}^{2+} /$ calmodulin-dependent protein kinase II alpha and beta isoforms in some structures of the rat forebrain. Brain Res 659:179-193.

Ouimet CC, McGuinness TL, Greengard P (1984) Immunocytochemical localization of calcium/calmodulin-dependent protein kinase II in rat brain. Proc Natl Acad Sci USA 81:5604-5608.

Pare D (2003) Role of the basolateral amygdala in memory consolidation. Prog Neurobiol 70:409-420.

Paxinos G, Watson C (1998) The rat brain in stereotaxic coordinates, Ed 4. London: Academic.

Perez-Jaranay JM, Vives F (1991) Electrophysiological study of the response of medial prefrontal cortex neurons to stimulation of the basolateral nucleus of the amygdala in the rat. Brain Res 564:97-101.

Pinaudeau-Nasarre C, Gaillard A, Roger M (2002) Timing and plasticity of specification of CaM-Kinase II alpha expression by neocortical neurons. Brain Res Dev Brain Res 138:97-107.

Rosenkranz JA, Grace AA (2001) Dopamine attenuates prefrontal cortical suppression of sensory inputs to the basolateral amygdala of rats. J Neurosci 21:4090-4103.

Rosenkranz JA, Grace AA (2002) Cellular mechanisms of infralimbic and prelimbic prefrontal cortical inhibition and dopaminergic modulation of basolateral amygdala neurons in vivo. J Neurosci 22:324-337.

See RE (2002) Neural substrates of conditioned-cued relapse to drugseeking behavior. Pharmacol Biochem Behav 71:517-529.

Taylor CL, Latimer MP, Winn P (2003) Impaired delayed spatial win-shift behaviour on the eight arm radial maze following excitotoxic lesions of the medial prefrontal cortex in the rat. Behav Brain Res 147:107-114.

Thomas KL, Everitt BJ (2001) Limbic-cortical-ventral striatal activation during retrieval of a discrete cocaine-associated stimulus: a cellular imaging study with $\gamma$ protein kinase C expression. J Neurosci 21:2526-2535.

Tzschentke TM, Schmidt WJ (1999) Functional heterogeneity of the rat 
medial prefrontal cortex: effects of discrete subarea-specific lesions on drug-induced conditioned place preference and behavioural sensitization. Eur J Neurosci 11:4099-4109.

Wang GJ, Volkow ND, Fowler JS, Cervany P, Hitzemann RJ, Pappas NR, Wong CT, Felder C (1999) Regional brain metabolic activation during craving elicited by recall of previous drug experiences. Life Sci 64:775-784.

Weiss F, Maldonado-Vlaar CS, Parsons LH, Kerr TM, Smith DL, Ben-Shahar O (2000) Control of cocaine-seeking behavior by drug-associated stimuli in rats: effects on recovery of extinguished operant-responding and extracellular dopamine levels in amygdala and nucleus accumbens. Proc Natl Acad Sci USA 97:4321-4326.
Weissenborn R, Robbins TW, Everitt BJ (1997) Effects of medial prefrontal or anterior cingulate cortex lesions on responding for cocaine under fixed-ratio and second-order schedules of reinforcement in rats. Psychopharmacology (Berl) 134:242-257.

Whitelaw RB, Markou A, Robbins TW, Everitt BJ (1996) Excitotoxic lesions of the basolateral amygdala impair the acquisition of cocaine-seeking behaviour under a second-order schedule of reinforcement. Psychopharmacology (Berl) 127:213-224.

Zavala AR, Weber SM, Rice HJ, Alleweireldt AT, Neisewander JL (2003) Role of the prelimbic subregion of the medial prefrontal cortex in acquisition, extinction and reinstatement of cocaine-conditioned place preference. Brain Res 990:157-164. 